УДК 343.6

DOI https://doi.org/10.32849/2663-5313/2019.5.44

\title{
Карина Корнієнкова,
}

студентка міжнародно-правового факультету

Національного юридичного університету імені Ярослава Мудрого

\section{КРИМІНАЛЬНА ВІДПОВІДАЛЬНІСТЬ ЗА ДОВЕДЕННЯ ДО САМОГУБСТВА}

Стаття присвячена аналізу складу злочину, передбаченого статтею 120 Кримінального кодексу України. Досліджено проблемні аспекти, що містяться у диспозииї даної статті та встановлено необхідність вдосконалення чинного закону про кримінальну відповідальність. Проаналізовано способи вчинення даного злочину.

Ключові слова: доведення до самогубства, жорстоке поводження, шантаж, примус до протиправних дій, систематичне приниження людської гідності.

Постановка проблеми. Найвищою соціальною цінністю в Україні є людина, іï життя та здоров'я. У Конституції України вказано, що кожна людина має невід'ємне право на життя і ніхто не може бути свавільно його позбавлений. Проте нині у країні збільшився рівень смертності внаслідок здійснення самогубств. Самогубства вчиняються 3 різних причин (соціальних, психологічних, економічних), а також $€$ наслідком злочинів, зокрема доведення до самогубства. Кваліфікація даного злочину викликає певні труднощі у правозастосовній діяльності. Найчастіше ці проблеми виникають у встановленні вини, причинного зв'язку між діями винного та смертю потерпілого. Також певні складнощі можуть виникнути у відмежуванні доведення до самогубства від суміжних складів злочину.

Аналіз останніх досліджень та публікацій. Питання кримінальної відповідальності за доведення до самогубства було предметом досліджень таких науковців, як: В.Ю. Баулін, О.А. Гусак, Л.І. Керик, В.О. Кірієнко, О.О. Колінько, Н.М. Ярмиш та ін.

Метою статті $є$ аналіз елементів складу злочину, передбаченого ст. 120 КК України, та дослідження способів доведення до самогубства.

Виклад основного матеріалу. Самогубство - умисне спричинення власної смерті, часто вчинене з відчаю, причину якого часто відносять до психічних розладів. Але саме по собі самогубство не є злочинним діянням. Злочинними є саме діяння, які призвели до таких дій, тобто доведення до самогубства. Суспільна небезпечність даного злочину підтверджується його об'єктом, тобто благом, на яке спричинено посягання. Такий злочин, як доведення до самогубства, завдає шкоди, яка не має відповідного еквіваленту: людина позбавляється найціннішого - життя.

Стаття 120 КК України передбачає кримінальну відповідальність за доведення особи до самогубства або до замаху на самогубство, яке (доведення) вчиняється шляхом жорстокого 3 нею поводження, шантажу, примусу до протиправних дій або систематичного приниження іï людської гідності. Особливістю цього злочину є те що, суспільно небезпечні наслідки спричиняються не безпосередньо винним, не його діями, які прямо спрямовані на заподіяння смерті. Потерпілий сам позбавляє себе життя у результаті певних дій винного. Для того щоб визначити проблемні питання кваліфікації даного злочину, необхідно ретельно проаналізувати кожен його елемент.

Почати насамперед потрібно саме 3 об'єкта даного злочину. Під об'єктом розуміється сукупність суспільних відносин, інтересів, які охороняються законом про кримінальну відповідальність та яким у процесі вчинення злочину заподіюється або створюється загроза заподіяння шкоди. Він має важливе практичне значення, оскільки допомагає відмежувати злочин від інших суміжних складів злочину. Стаття 120 знаходиться у Розділі II «Злочини проти життя та здоров'я особи» Особливої частини Кримінального кодексу України. Доведення до самогубства належить до злочинів середньої тяжкості на відміну від інших злочинів, які містяться у даному розділі. Вони є особливо тяжкими, за винятком привілейованих складів злочину. Розглядаючи питання про злочини проти життя та здоров'я, теорія кримінального права поняття «людина» і «особа» використовуе як синоніми. Проте людина як біологічна істота має невід'ємне суб'єктивне право на життя, тобто на своє біологічне існування. Це право з'являється в неї із самого народжен- 
ня і закінчується біологічною смертю. Тому абсолютно справедливим є твердження, що безпосереднім об'єктом зазначених злочинів $є$ життя будь-якої людини незалежно від його соціальної значущості й корисності [1, с. 172]. Також із диспозиції даної статті, яка містить такий спосіб доведення до самогубства, як систематичне приниження людської гідності, можна дійти висновку, що додатковим альтернативним об'єктом тут виступає людська гідність. Винний здійснює такий психологічний вплив на потерпілого, який відіграє вирішальну роль у виборі потерпілого позбавити себе життя. Психологічний вплив викликає у жертви такі негативні стани, як фрустрація, депресія, стрес, афект, почуття страху, беззахисність, образа, безсилля, замкненість тощо, які й призводять часто до самогубства. Тобто злочинець моделює свою поведінку, щоб спровокувати жертву до замаху на самогубство.

Щодо об́'єктивної сторони, то вона визначає зовнішню сторону злочину. Об'єктивною стороною є діяння у формі: 1) жорстокого поводження з особою; 2) шантажу; 3) примусу до протиправних дій; 4) систематичного приниження людської гідності потерпілого, яке призводить до такого наслідку, як самогубство або ж замах на нього. Але відповідальність можлива лише, якщо особу підштовхнули до самогубства неправомірними діями, які передбачені нормою КК України. Отже, перший спосіб - жорстоке поводження, яке $є$ оціночним поняттям. Відповідно до Постанови Пленуму Верховного Суду України «Про судову практику в справах про злочини проти життя та здоров'я особи» під жорстоким поводженням слід розуміти безжалісні, грубі діяння, які завдають потерпілому фізичних чи психічних страждань (мордування, систематичне заподіяння тілесних ушкоджень чи побоїв, позбавлення їжі, води, одягу, житла тощо) [2]. У криміналістиці це поняття розглядається як найвищий ступінь приниження індивіда. Для того, щоб у кожному конкретному випадку визначити цю міру приниження особистої гідності, людини слід установити: (а) обсяг прав та обов'язків обвинуваченого й потерпілого, у тому числі відносини, їх взаємозалежності; (б) психологічну характеристику потерпілого (його темперамент, характер, звички, фізіологічний стан); (в) ставлення обвинуваченого до наслідків своїх вчинків [3, с. 187].

У науковій літературі містяться різні визначення поняття «шантаж». Одні автори зазначають, що шантаж - це погроза (залякування погрозою) розголосити відомості, які потерпілий бажає зберегти в таємниці, або такі, що можуть його принизити чи скомпрометувати (відомості про хворобу, позашлюбні стосунки тощо) [4, с. 88]. Ці відомості можуть бути як правдивими, так і неправдивими. Важливо, що вони мають такий характер, що потерпілий не бажає їх розголошувати. Інші зазначають, що це залякування потерпілого якимись негативними наслідками, що можуть настати для нього чи його близьких, якщо потерпілий не вчинить певну дію (кілька дій) або не утримається від iii (ï) вчинення [5, с. 235].

Під примусом до протиправних дій більшість науковців розуміють фізичний або психічний вплив на особу з метою спонукання іï до дій, вчинення яких заборонено законодавством [6, с. 55]. О.А. Гусак, у свою чергу, пропонує замінити слово «протиправних» на слова «небажаних для потерпілого», оскільки особу можна довести до самогубства шляхом примушування її до дій, які є правомірними, але небажаними для потерпілого.

Постанова Пленуму Верховного Суду України «Про судову практику в справах про злочини проти життя та здоров'я особи» у п. 28 зазначає, що систематичним приниженням людської гідності є тривале принизливе ставлення до потерпілого (постійні образи, знущання над ним тощо) [2]. Судова практика не відносить до такого роду обставин розірвання шлюбних відносин одним із подружжя, відмову від укладання шлюбу, припинення співжиття, подружню зраду, якщо при цьому не здійснювалися інші дії, що принижують людську гідність. Не можуть також кваліфікуватися за ст. 120 КК випадки самогубства внаслідок вчинення щодо особи будь-яких законних дій (наприклад, правомірного звільнення 3 роботи), а також внаслідок повідомлення хоча й таких, що принижують гідність особи, але достовірних, таких, що відповідають дійсності, відомостей (за умови, що вони повідомлялися не в образливій чи цинічній формі) [6, с. 55].

Д.О. Міскі цілком слушно ставить запитання: «Проаналізовані форми - це діяння чи спосіб доведення до самогубства?» Проаналізувавши визначення діяння як обов'язкової ознаки об'єктивної сторони складу злочину та способу вчинення злочину - як факультативної ознаки, можна дійти висновку, що аналізовані форми доведення до самогубства виступатимуть способом, що збігається 3 дією, а саме жорстоким поводженням, шантажем, примусом до протиправних дій, систематичним приниженням людської гідності потерпілої особи [4, с. 89].

Даний злочин має матеріальний склад, який $є$ закінченим 3 моменту доведення до самогубства або замаху на нього. Також він 
належить, як правило, до продовжуваних злочинів, адже насильство може бути вчинене в одному місці, а потерпілий може вчинити самогубство в іншому.

Суб'єктивна сторона злочину - це внутрішня сторона злочину, психічна діяльність особи, що відображає їі ставлення до діяння, що нею вчиняється, та до суспільно небезпечних наслідків, що настали. Зміст психічного ставлення особи до діяння та наслідків може бути з'ясований за допомогою аналізу об'єктивної сторони злочину. Оскільки даний злочин має матеріальний склад, то припускається наявність суспільно небезпечного діяння, його наслідків та причинного зв'язку між ними. Якщо злочин вважається закінченим з моменту настання певних наслідків, то обов'язковим $€$ визначення психічного ставлення особи, що вчинила суспільно небезпечне діяння, до наслідків, що настали. Обов'язковою ознакою суб'єктивної сторони є вина. Одні автори вважають, що доведення до самогубства може бути вчинене у формі як умислу, так і необережності [7, с. 889]. Інші автори вважають, що доведення до самогубства або замаху на нього може бути вчинене як із прямим, так і з непрямим умислом. Цілком обгрунтованою є думка О.А. Гусак, яка вважає, що даний злочин може бути здійснений тільки у формі прямого умислу, адже для кваліфікації даного злочину необхідним є встановлення саме цілеспрямованих дій особи, що сприяли формуванню рішучості потерпілого на позбавлення себе життя. Тобто дії винного, в результаті яких потерпілий вчинив самогубство, повинні чітко відображати прагнення винного до того, щоб потерпілий вибрав саме цей варіант поведінки. Інакше будь-який факт самогубства в результаті якого-небудь зовнішнього впливу, навіть правомірного, що не має на меті доведення до самогубства особи, може розцінюватися як доведення до самогубства, наприклад словесні образи, негативні висловлювання, невдалі жарти, у результаті яких потерпілий вирішив позбавити себе життя [8, с. 213].

Існує певна складність встановлення причинного зв'язку між діями винного та смертю потерпілого, в результаті чого постає проблема доведення вини у даному злочину. Тому призначення та проведення різноманітних судових експертиз у справах про доведення до самогубства є одним 3 основних джерел отримання доказової інформації. Експертиза встановлює причину смерті потерпілого, психічний стан потерпілого, в якому він знаходився до вчинення самогубства, та чи є причинний зв'язок між діями обвинуваченого та психічним станом потерпілого [7, с. 890].

Суб́'єкт даного злочину - загальний, тобто фізична осудна особа, яка досягла 16-річного віку. Поведінка злочинця під час вчинення злочинних дій пов'язана 3 моральними, психологічними проявами та властивостями. Психологи в особі злочинця вирізняють такі дефекти: індивідуальну правосвідомість, патологію потреб сфери особистості та психічного розвитку. До найбільш загальних рис насильницьких злочинців відносять егоїзм, нехтування інтересів і думки членів суспільства, відсутність здатності й бажання поставити себе на місце потерпілого, жорстокість, афективний характер поведінки [9, с. 88-92]. Оскільки саме самогубство або замах на нього кримінальної відповідальності не тягне, підбурювання до самогубства і пособництво в самогубстві також не караються законом [6, с. 56]

\section{Висновки}

Доведення до самогубства є специфічним злочином, оскільки саме самогубство є видом неприродної смерті, але даний злочин є єдиним проти життя особи, який не охоплюється поняттям «вбивство», адже вчиняється не безпосередньо винним, а потерпілим, тобто опосередковано. Проблема суїциду натепер є актуальною не лише в Україні, а в багатьох країнах світу. Причинами є як зовнішні проблеми в державі, так і особисті проблеми людини. Наявність численних розробок із даної проблеми свідчить про наявність недоліків у чинному законодавстві України. Одним із таких недоліків € відсутність кримінальної відповідальності за схиляння особи до самогубства. Також проблемні аспекти містить диспозиція ст. 120 КК, яка не перелічує всіх видів діянь, якими може вчинюватися даний злочин, наприклад таких, як підкуп, обман, сприяння вчиненню самогубства. Тобто кримінальна відповідальність у таких випадках відсутня.

\section{Список використаних джерел:}

1. Гусак О.А. Об'єкт доведення до самогубства: сучасний погляд. Вісник Одеського національного університету. Правознавство. 2012. Т. 17. Вип. 1/2 (16/17). С. 171-175.

2. Про судову практику в справах про злочини проти життя та здоров'я особи : Постанова Пленуму Верховного Суду України від 07.02.2003 № 2. Вісник Верховного Суду України. 2003. № 1. П. 31.

3. Керик Л.І. Способи доведення до самогубства. Проблеми законності: Респ. міжвідом. наук. зб. / відп. ред. В. Я. Тацій. Харків: Нац. юрид. акад. України, 2008. Вип. 96. С. 186-191.

4. Міскі Д.О. До проблеми визначення об'єктивної сторони доведення до самогубства. 
Юридичні науки:проблеми та перспективи (м. Івано-Франківськ, 19-20 травня 2017 р.). Херсон : Видавничий дім «Гельветика», 2017. С. 87-89.

5. Науково-практичний коментар до Кримінального кодексу України / за заг. ред. С.С. Яценка. Київ : А.С.К., 2002. 936 с.

6. Кримінальне право України: Особлива частина: підручник / Ю.В. Баулін, В.І. Борисов, В.І. Тютюгін та ін. / за ред. проф. В.Я Тація, В.І. Борисова, B.I. Тютюгіна. Харків : Право, 2015. 680 с
7. Кривоконь Д. А. Доведення до самогубства: кримінально-правовий аналіз. Молодий вчений. 2017. № 11. С. $888-892$.

8. Гусак О.А. Кримінально-правова характеристика суб'єктивної сторони доведення до самогубства. Актуальні проблеми держави $і$ права. 2013. Вип. 69. С. 211-215.

9. Коновалова В.Е. Основы юридической психологии : учебник / за ред. В.Е. Коновалова, В.Ю. Шепитько. Харьков : Одиссей, 2005. 352 с.

Статья посвящена анализу состава преступления, предусмотренного статьей 120 Уголовного кодекса Украины. Исследовано проблемные аспекты, содержащиеся в диспозици данной статьи, и установлена необходимость совершенствования действующего закона об уголовной ответственности. Проанализированы способы совершения данного преступления.

Ключевые слова: доведение до самоубийства, жестокое обращение, шантаж, принуждение к противоправным действиям, систематическое унижение человеческого достоинства.

The article is devoted to the analysis of the crime provided by article 120 of the Criminal Code of Ukraine. The problematic aspects contained in the disposition of this article and the need to improve the current law on criminal liability are identified. The ways of committing this crime are analyzed.

Key words: finishing before suicide, abuse, blackmail, coercion to unlawful acts, systematic humiliation of human dignity. 